\title{
Contrastive Linguistic and Cultural Backgrounds of the Two Latin Translators of the Life of Antony
}

\section{Aleksandar Anđelović and György Geréby ${ }^{\star *}$}

\section{INTRODUCTION}

Soon after its composition, Athanasius' Life of Antony (henceforth Life) was translated twice from Greek into Latin. ${ }^{1}$ One version originated in about $375 \mathrm{CE}$, written by Evagrius, ${ }^{2}$ a Christian intellectual from Antioch in Syria, a close friend and patron of Jerome, whose career and

* Department of History, University of Vienna, Maria-Theresen-Straße 9, 1090 Wien; aleksandar.andjelovic@univie.ac.at.

* Department of Medieval Studies, Central European University, Quellenstraße 51, A-110oWien, gerebygy@ceu.edu.

1 Athanasius' authorship of the Life of Antony has been the subject of numerous debates. Apart from Athanasian paternity, the question has also been whether the Greek text preserved is a revision of an original, now lost, Coptic text and whether the Syriac Life that we have translates an original "Copticizing" Greek text or an original Coptic; for a brief overview, see Louth, "St. Athanasius and the Greek Life of Antony," 504-5. Given the lack of evidence of any other Vorlage than the extant Greek Life, one can agree with David Brakke that the extant Greek Life of Antony is the earliest form of Antony's biography; for details regarding his arguments, see Brakke, "The Greek and Syriac versions of the Life of Antony," 53.

2 The critical edition of Evagrius' translation (henceforth $V E$ ) used in this article is Vitae Antonii Versiones latinae, Vita beati Antonii abbatis Evagrio interprete, ed. by Bertrand, 3-103. 
personality are relatively easy to trace $^{3}$ in the extant ancient sources. ${ }^{4}$ Evagrius' Latin translation became very popular in the Latin West. It was widely read during the Middle Ages, as witnessed by more than four hundred manuscripts in which it has survived. It was composed in a high register of Latin. Evagrius sprinkled the text with classical quotations such as Vergil and Horace, and it was written probably for a late-antique elite readership.

Evagrius' translation (henceforth VE) was long believed to be the only translation of the Greek Life. In 1914, however, the French Benedictine medievalist and liturgist Dom André Wilmart found a manuscript in the Archives of the Chapter of Saint Peter in Rome. ${ }^{5}$ Wilmart identified it as an eleventh-century copy of an older Latin translation of the Greek Life of Antony produced some twenty years before vE. The first edition of the text was published some twenty-five years after its discovery. ${ }^{6}$ This anonymous translator's (henceforth AT) work, unlike Evagrius' celebrated translation, was disregarded by scholarship as being too literal, labeled as "barbarous," "low," "monastic," or "Christian” Latin, written for uneducated monks.?

Who was the $\mathrm{AT}$ ? Unlike his later counterpart Evagrius, the author of the first Latin translation of the Life remains an unknown figure despite several attempts to uncover his identity. ${ }^{8}$ Henricus Hoppenbrouwers speculated that he was a prominent Egyptian monk named Isidore. Lois Gandt, the most recent editor of the anonymous trans-

3 In any case, both translators worked with the Greek text they believed to have been authored by Athanasius; for the current purposes, the question of whether there existed an earlier redaction of the Life of Antony in Coptic or "Copticizing" Greek is irrelevant. The critical edition of the Greek Life of Antony (henceforth va) used in this paper is Bartelink, Sant'Antonio Abate, based on the Greek text of the VA published by Bartelink, Vie d'Antoine.

4 For an overview of Evagrius' life see Rebenich, Hieronymus und sein Kreis, 52-75. See also Bertrand, "Die Evagriusübersetzung der Vita Antonii: Reception Überlieferung - Edition,” 24-28.

5 Available online in the digital database of the Vatican Library, "Arch.Cap.S.Pietro.A.2," DigiVatLib.

6 Garitte, Un témoin important. The critical edition of the anonymous translation (henceforth VV) used in this article is Vitae Antonii Versiones latinae, Versio uetustissima, ed. by Lois Gandt, 107-177.

7 For a brief overview of the theories on "Christian" Latin developed by the so-called Nijmegen school, see Burton, The Old Latin Gospels, 153-54. The notion of "Christian" Latin as Sondersprache is now outdated, and it never lacked critics, see, for example, the most recent publications on this topic, Denecker, "Among Latinists," as well as "The Nijmegen School."

8 For the little that is known about the AT, see ed. Gandt, 205-8. 
lation (henceforth $V V$ ), identified this AT with another well-known Egyptian erudite monk, Ammonius. ${ }^{9}$ Still, it is unlikely that one will ever know the actual name of the translator. Therefore, while one can agree that the AT probably originates from Egypt, ${ }^{10}$ rather than attempting to identify him with one or another well-known figure of fourth-century Egyptian monasticism, this paper will try to glean information on the AT from the translation's text. This approach, particularly beneficial in the case of the AT, works even in Evagrius' case. His text has not been fully quarried for information about its translator either.

In particular, given that the Greek Life is suffused with biblical quotations as Athanasius widely quoted the Bible in shaping Antony as a normative and monastic model, ${ }^{11}$ the biblical quotations that both translators translated from Greek in their versions of the Life reveal a lot about the two translators' distinctive modus operandi. When saying this, one can have in mind the direct quotations (i.e., quotations with no or minimal change in respect to their original formulation in the Greek Bible, henceforth verbatim) from the Bible rendered into Latin that each translator did in his way. Thus, the translations of verbatim biblical quotations from Greek into Latin have the potential to reveal more about the two translators' approaches to translation and about their linguistic, cultural, and theological background than is known so far.

Did the AT of the Life use any of the existing Latin translations of the Bible to translate the biblical quotations he found in the Greek original, or did he translate them himself, without recourse to translations already available? What does the AT's "literal" and "low-

9 Another fourth-century desert ascetic and one of the Tall Brothers, the four monks from Nitria known for their exceptional height as well as for erudition, see Gandt, "A Philological and Theological Analysis," 298.

10 Primarily because of his familiarity with the Egyptian desert, as rightly noticed by Gandt, see ibid., 73 .

11 It is difficult to give a precise number, but the biblical quotations in the Life seem to come in hundreds. See, for instance, Bartelink, "Die literarische Gattung," 52, where the number of Bible-related passages is estimated at two hundred. An even more generous assessment is given by Tim Vivian, who performed a "rough count" resulting in "some four hundred references or allusions" in Athanasius, The Life of Antony, xxvi, trans. by Tim Vivian and Apostolos N. Athanassakis. The text of the Greek Old Testament used in this article is the latest standard edition of the Lxx, published by Rahlfs and Hanhart, Septuaginta. The text of the Greek New Testament used in this article is Karakolis, Novum Testamentum Graece. 
register" style tell us about the translator? What version of the Bible did he use when translating the Bible in Latin or Greek? On the other hand, what does Evagrius' "high" and stylistically sophisticated and improved Latin tell us about Evagrius? Whom does he write for, and what do his readers expect from him? This paper aims at answering these questions.

\section{THE ANONYMOUS TRANSLATOR: WHAT WAS \\ THE LANGUAGE OF THE BIBLE HE USED - AND WAS LATIN HIS NATIVE LANGUAGE?}

An initial research question is whether the biblical quotations in Latin that the Ат rendered from Greek as part of his translation of the Life are attested in other Latin writings of the period - or did he translate the biblical quotations by himself? The same question will then be asked about Evagrius and his translation. The answer determines the extent to which the AT and Evagrius used any translation of the Bible circulating in the fourth century.

In chapter 48.3 of the Life, Athanasius justified the miracles performed by Antony with a quote from the Gospels: Пo $\lambda \lambda \dot{\alpha} \tau \varepsilon$ кaì

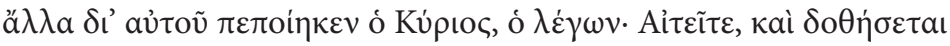
v $\mu v_{v}{ }^{12}$ The AT rendered this as follows: Multa et alia per seruum suum Dominus fecit qui dicit: Postulate et dabitur uobis. ${ }^{13}$ On the other hand, Evagrius translated the same passage as Multa et alia miracula per illum Dominus operatus est, et merito: qui enim promisit in Euangelio: Petite et dabitur uobis. ${ }^{14}$ The biblical quotation in Athanasius' Greek text reproduced Matt. 7:7 or Luke 11:9 verbatim, and the different ways the two translators rendered this short passage illustrate their different modus operandi. ${ }^{15}$ First, how the AT, on the one hand, and Evagrius, on the other, introduce the quotation is particularly interesting. While the AT, apart from translating "through him" ( $\delta l$ ' av่toṽ) as "through through him [Antony] did the Lord, who says: 'Ask, and it will be given to you."' (Trans. Vivian and Athanassakis, 161-63, slightly changed.)

VV 48 (ed. Gandt, 145): "Many other things through his servant did the Lord, who said: 'Require, and it will be given to you."' Translations of the vv from Latin into English are by the authors unless indicated otherwise.

$14 V E 48$ (ed. Gandt, 54): "The Lord also worked many other miracles through Antony, and justly so, for He who promised in the Gospel, Ask and it will be given to you" (trans. White, 38 ).

15 In the Bertrand-Gandt edition, this passage is not recognized as a verbatim biblical quotation. 
his servant" (per seruum suum), ${ }^{16}$ simply renders ó $\lambda \dot{\varepsilon} \gamma \omega v$ ([the Lord,] who says) as "[the Lord] says" (dicit), Evagrius used a different verb, "he promised" (promisit), which enhances the meaning of the original and can be considered an exegetic translation, as opposed to the simple translation of the Ат. What is more, Evagrius added a precise textual reference "in the Gospel" (in Euangelio), absent from both the Greek original and the earlier AT. Evagrius may have wanted to demonstrate his accurate knowledge of the Bible, or, more probably, he deemed it necessary to provide his readers with an immediately identifiable context. This case further raises the question of his intended readership that could have made necessary such an indication about the origin of the biblical passage quoted. Possible alternatives are that his intended audience was made up of recent converts to Christianity or elite non-Christians unfamiliar with the Bible, or an elite readership already familiar with the Bible for whom he was providing not just instruction but also reassurance about the message of the text (promisit) as a means of articulating a specific Christian identity.

The difference between the verbal forms postulate used by the АT and Evagrius' petite is significant; petite et dabitur uobis was the "standard" rendering of this biblical passage, widely used in the late-antique texts, and, in addition to Evagrius, also attested in the revised Old Latin Gospels that became part of the Vulgate. ${ }^{17}$ It was also adopted by Ambrose, ${ }^{18}$ Ambrosiaster ${ }^{19}$ Arnobius, ${ }^{20}$ Augustine, ${ }^{21}$ Hilary of Poitiers, ${ }^{22}$ and Jerome. ${ }^{23}$ The choice of the AT, postulate, is never attested outside his translation. It suggests that the AT translated without knowing about the existing Latin translation of the Gospels. On the other hand, Evagrius was undoubtedly familiar with an established and widely circulating Latin version.

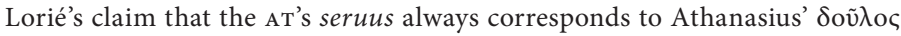
("slave") is therefore incorrect, as evidenced by this biblical quotation of the VA,

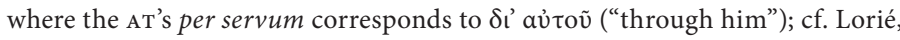
Spiritual Terminology, 87 .

17 The text of the Vulgate used in this article is Biblia Sacra iuxta vulgatam versionem, ed. Robert Weber, 5 th ed. by Roger Gryson; available, without the critical apparatus, in a searchable electronic format in the Library of Latin Texts (LLT). Cain et $A b$. 1.6. The abbreviations used in this paper are made according to the "TLL Digital Index," Thesaurus linguae Latinae (TLL), available online.

19 Quaest. 115.82.

20 Praedest. 3.12.

21 In Psalm. 139.17.

22 Tract. 60.4.

23 In Matth. 1. 
This example further shows that the AT may have operated with a standard equivalence for ai $1 \varepsilon \dot{c} \omega$, "ask for, demand," always translated with postulare, both in direct Bible quotations and in the other parts of the Life. ${ }^{24}$ This translation choice, apart from illustrating the literal nature of the $v V$, also offers a clue to the linguistic background of the translator, who elsewhere constructed the Latin verb postulare with a direct object in the accusative (Dominum, "Lord").25 This usage is rarely attested in standard Latin, ${ }^{26}$ where an indirect object in the ablative with the preposition $a$, "from," would have been the more common option, as Evagrius' rendering of the same construction illustrates. ${ }^{27}$ This peculiar choice of the AT can be explained as a mirror translation of the Greek syntactic structure. The verb "to ask for" (aitź $\omega$ ) is typically constructed with the accusative. ${ }^{28}$ This kind of equivalence is a characteristic feature of translations produced by bilingual speakers with insufficient command in the target language. ${ }^{29}$

This example is by no means the only one where the translations produced by the AT strongly suggest that he was unfamiliar with the versions of the Latin Bible text circulating in the second half

24 See, for example, the reference to John 16:23-24 in VA 83.3 (ed. Bartelink, 404):

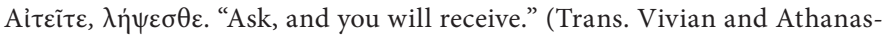
sakis, 237.) See also VV 83 (ed. Gandt, 169): Postulate et accipietis. Compare this to the non-biblical context in VA 29.3 (ed. Bartelink, 249): El̉ $\gamma$ à $\rho$ lo $\sigma \nu \sigma \varepsilon v$,

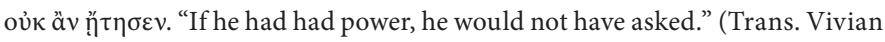
and Athanassakis, 125.) See also VV 29 (ed. Gandt, 132): si enim ualuisset, non postulasset.

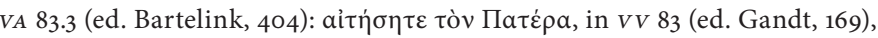
translated as postulaueritis Patrem meum.

On the standard usage of postulare, see the Oxford Latin Dictionary (henceforth $O L D), 1557$ s.v. postulo, section 1. For the very few attested examples of the so-called ablative of person, see Löfstedt, Commento Filologico, 274-275. VE 34 (ed. Gandt, 40): ab auxiliatore Domino postulare.

28 See Diccionario Griego-Español, 121-122, s.v. Aìć่w. Apart from mirror translations, the AT also employed mechanical translations, for example, his de cetero was used automatically as an equivalent of $\lambda$ ot $\pi$ óv, either in a biblical quotation or elsewhere in Athanasius' text. See, for example,

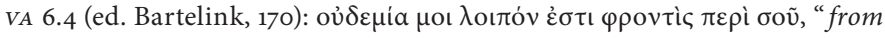
now on I am not going to pay any attention to you" (trans. Vivian and Athanassakis, 73), and the AT's nulla de cetero sollicitudo est de te, VV 6 (ed. Gandt, 113): "no care about you anymore." The same equivalence occurs with $\lambda$ otróv in VA 3.7, 4.2, 6.1, 7.7, 14.7, 23.6, 25.3, 31.1, 37.2, 50.9, 90.6, 91.9, and de cetero in the corresponding chapters of $V V$ (Bertrand and Gandt, Vitae Antonii Versiones latinae). 
of the fourth century.$^{30}$ His ignorance in this and other cases of the existing versions of the Bible in Latin suggests that the Bible text he regarded as authoritative was in a language other than Latin. In several instances, the AT produced a text different from the original Greek text of the Life and Evagrius. In these instances, one finds the AT either omitting a portion of the Greek text or adding a (more) complete form of a biblical quotation absent from Athanasius' text. In the latter case, the AT's Latin translation often corresponds precisely to the relevant passage in the Greek Bible. The following example aims at providing arguments for the hypothesis that the Bible the AT used was in Greek.

At the beginning of the Life, Athanasius' Antony discusses traditional philosophical topics, like the definition of virtue, the transient nature of wealth and success, and the importance of an unceasing daily ascetic discipline..$^{31}$ To corroborate his statements, he refers to

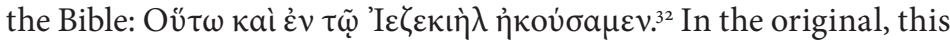
reference to a passage from the Book of Ezekiel is vague and does not contain the actual biblical text to which it alludes. Evagrius rendered the passage exactly as it stood in the Greek original: Quod prophetica per Ezechielem uoce testatur.33

The AT, on the other hand, expanded the original reference with several quotations from Ezekiel which, as mentioned above, he could not have found in the Athanasian text that served as the basis for his translation: Sic enim et in Ezechiel propheta audiuimus dicentem Dominum: Iustus si recesserit a iustitia sua et fecerit facinus, uiuo ego dicit Dominus, quia non memorabo iustitiae eius sed in eo quod fecit, in illo morietur. ${ }^{34}$ Interestingly, although constructed as one sentence, as quoted by the AT, this biblical passage is a combination of phrases taken from at least three passages of the Book of Ezekiel (known for its repetitive phraseology). These are as follows: Ezek. 3:20 (cf. 18:24 and 26): "when the righteous turn away from their righteousness and 28-58.

31 VA 16-20. See also Rousseau, "Antony as Teacher," 95.

32 VA 18.3 (ed. Bartelink, 212): “Thus we have also heard in Ezekiel." (Trans. Vivian and Athanassakis, 103.)

33 VE 18 (ed. Bertrand, 25): "as testified by the words of the prophet Ezechiel" (trans. White, 21).

34

18 (ed. Gandt, 123): "Thus we have also heard in the prophet Ezekiel the Lord saying: If a righteous person turns away from his righteousness and commits a crime, as I live says the Lord, [I am telling you] that I will not remember his righteousness, but in what he did, in that he will die." 
commit iniquity,"35 Ezek. 33:13: "none of their righteous deeds shall be remembered, but in the iniquity that they have committed they shall die, ${ }^{\prime 36}$ and the oft-repeated formulation found, for instance, in Ezek. 5:11: "(as) I live, says the Lord." ${ }^{37}$

Even though the phrase "I live, says the Lord" (uiuo ego dicit Dominus) is present in Jerome's translation of Ezekiel, later included in the Vulgate, it is unlikely that the AT and Jerome shared the same version of the Bible. It seems that the AT here quoted Ezekiel from memory and directly from the Greek. Such a "hybrid" quotation, or flattening, is characteristic of quoting from memory. ${ }^{38}$ The AT associated Athanasius' vague reference to Ezekiel with some of the most well-known phrases of the Book of Ezekiel, such as the formula "I live, says the Lord" (uino ego dicit Dominus), ${ }^{39}$ a word-for-word translation from $\zeta \tilde{\omega} \dot{\varepsilon} \gamma \dot{\omega}, \lambda \dot{\varepsilon} \gamma \varepsilon \iota$ kúpıos into Latin, which he used as a link between the other two quotations that he supplied from the text of Ezekiel. This formula is attested no less than thirteen times in the Book of Ezekiel alone..$^{40}$ The other quote, "if a righteous turns away from his righteousness and commits a crime" (iustus si recesserit a iustitia sua et fecerit facinus), is "flattened" out of at least three quotations similar to each other. ${ }^{41}$ The wording of these quotations from Ezekiel by AT is unattested elsewhere in Latin. The most likely explanation for how the AT rendered the additional material is that

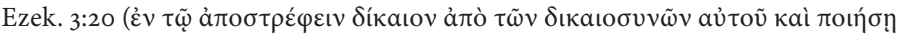

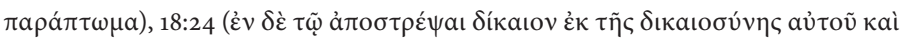

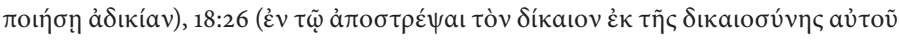

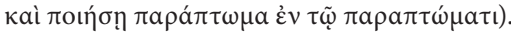

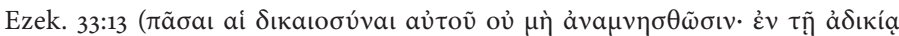

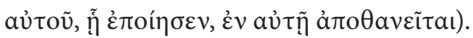

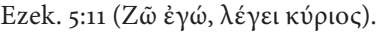

38 For the process of flattening, see Houghton, "'Flattening' in Latin Biblical Citations."

Bartelink noted how this formula found in the Old and the New Testament frequently introduced the oath of God and that the text of the AT differs considerably from Ezek. 18:24 in the Vulgate version, where there is no uiuo ego but uiuet with iustus as a subject, see his commentary in Bartelink, Vita di Antonio, 210, n. 14 .

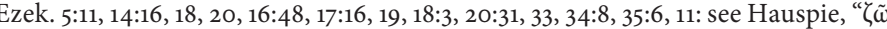

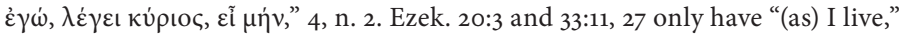
without "says the Lord." This formula is attested in the New Testament as well,

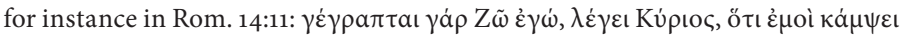

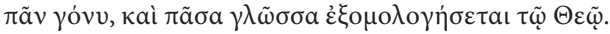


it resulted from quoting Ezekiel from memory in a language other than Latin, very likely Greek. ${ }^{42}$

One possible justification for such an intervention is that he deemed it necessary to provide his readers with immediately identifiable quotations. ${ }^{43}$ This suggestion is supported by the fact that the above-discussed example is by no means singular; there are several other places in his translation where he added biblical quotations or references absent from the Greek text. ${ }^{44}$ This fact further raises the question of what his intended readership could have been. The AT regarded a biblical reference without quotation as insufficient for his readers to understand the full context of this part of the Life, from which one can further deduce that he may have viewed his target readership as not familiar enough with the Bible. Another possible explanation might be that he wished to demonstrate his knowledge of the Bible by quoting it in fuller form.

The AT's ignorance of the Bible in Latin suggests that he was not a native speaker of Latin and had limited competence in the language. This deficiency is supported by several "mechanical" translations of Christian key terms in Greek. ${ }^{45}$ Fashioning Antony as fully adherent to "orthodox" theology was a powerful weapon in Athanasius' anti-Arian campaign. In chapter 69 of the Life, he wrote that "the Arians lied and said that Antony held the same beliefs as they." ${ }^{46}$ Here, Athanasius "depicted Antony as responding to this claim by appearing in Alexandria

42 For instance, the use of the verb in 1st person sg. "I will not remember" (non

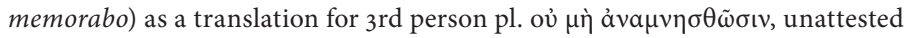
in other Christian writers of the time who quoted from Ezekiel, was influenced by the 1st person singular "I live" (uiuo ego).

43 The possibility that actual full quotations from Ezekiel may have been present in the initial text of the Greek Life should be discarded, as there are no manuscripts of the Greek Life that attest such a version of the text, see VA 18.3 (ed. Bartelink, 212, with the apparatus ad loc.). As shown, there is no trace of these quotations in $V E$ either.

44 See also VA 17.5, where the AT added the whole text of Eccles. 4:8, 6:2, absent from Athanasius' text, or VA 51.1, where he added a reference absent from the Greek original, ut scriptum est in Iob, "as it is written in Job." For other such interventions of the AT, see Gandt, "A Philological and Theological Analysis," 82-83.

45 The term mechanical is used in this article as equal to non-idiomatic and word-for-word approach to translation, resulting in an automatic equivalence between words translated from one language to another, in this case from Greek into Latin, as opposed to a language choice that is seen as idiomatic and dynamic. For the use of such terminology see, for instance, Adams, Bilingualism, 37.

46 Trans. Vivian and Athanassakis, 205. 
and publicly denouncing Arian thought," ${ }^{47}$ which he characterized as "ungodly." ${ }^{8}$ As usual, when treating critical theological issues, Athanasius lent authority to Antony's words by quoting the Bible: "O$\theta \varepsilon v$

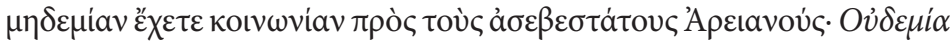

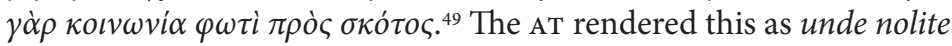
habere cum impiis, ipsi Ariani, ullam communicationem, nulla enim communicatio lucis cum tenebra..$^{50} \mathrm{VE}$ of the passage reads as follows: cum Arianis sit uobis nulla coniunctio. Quae enim societas luci ad tenebras? ${ }^{\text {1 }}$

The two translators' renderings differ significantly. First, it should be noted that Athanasius' "for light has no fellowship with darkness" is not a verbatim biblical quotation but instead his reworking of a question into a negative statement..$^{52}$ The quotation that Athanasius "flattened" here is 2 Cor. 6:14, which reads: "what fellowship can light have with

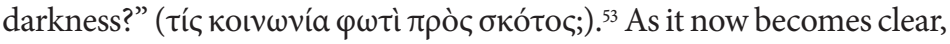
this is precisely how Evagrius translated it, as a question. In other words, he recognized 2 Cor. 6:14 in the Greek text and decided to translate the rhetorical question of the biblical original, not Athanasius' negative "answer" to it. Furthermore, it seems likely that Evagrius did not simply translate the Bible anew here but used an already existing version of 2 Cor. 6:14 in Latin, as attested in Rufinus' translation of Origen, ${ }^{54}$ Paulinus of Nola, ${ }^{55}$ Chromatius, ${ }^{56}$ Augustine, ${ }^{57}$ and Jerome. ${ }^{58}$

Ibid., 135 .

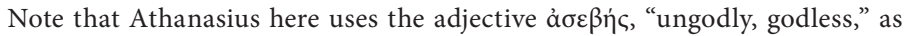

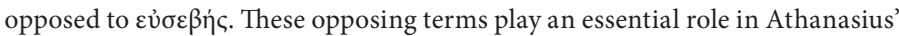
theological discourse and anti-Arian propaganda.

VA 69.4-5 (ed. Bartelink, 362): "As a result, you are to have no fellowship with the godless and iniquitous Arians, for 'light has no fellowship with darkness." (Trans. Vivian and Athanassakis, 205.)

VV 69 (ed. Gandt, 159, slightly altered, retaining Bartelink's reading communicationem, which is that of the manuscript against communicatione printed in Gandt's edition): "Hence, do not have with the godless, the Arians, any fellowship, for light has no fellowship with darkness."

VE 69 (ed. Bertrand, 76): "You must have nothing to do with the Arians. For what fellowship can there be between light and darkness?" (Trans. White, 52.)

The same as in the case of VA 9.2, "nothing 'will separate me from the love of Christ'," and Rom. 8:35, "who will separate us from the love of Christ?" See Anđelović, "Between the Literal and the Literary," 28-30.

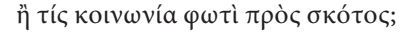

Orig. in Leu. 4.4.

Epist. 1.8.

In Matth. 31.

Spec. 32.

In Is. 14.52. 
In contrast to $V E$, the rendering of the AT reflects his low-register Latin usage and is otherwise unattested, ${ }^{59}$ which suggests that the translator translated without prior knowledge of existing versions of the Bible in Latin. While кoเvwvía, "fellowship," which appears twice in the Greek original, was translated by Evagrius first as coniunctio and then, in keeping with the established form of 2 Cor. 6:14 in Latin in Late Antiquity, as societas, the AT used communicatio in both instances. Although communicatio was not uncommon as a Latin translation for Kolvwvia in biblical contexts, ${ }^{60}$ the AT used communicatio and com-

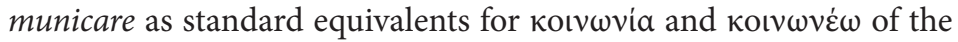
Greek original as if working with a dictionary or a bilingual glossary. ${ }^{61}$ In contrast, $V E$ of the same passages renders these terms with a more lexical variety in a more idiomatic and rhetorically elaborated fashion. ${ }^{62}$

The examples discussed indicate that the text of the Bible that the AT used in personal and liturgical contexts was not in Latin but very likely in Greek. Bearing in mind the importance of the Scriptures in Christian monastic circles in the fourth century, this would thus further

59 The apposition in the nominative ipsi Ariani is, according to Bartelink, a lowregister construction. See his commentary ad loc. in Bartelink, Vite dei Santi, 253, n. 12. Also, the use of tenebrae, -arum in the singular (such as in "cum tenebra") is rarely attested in standard Latin, see ibid., n. 13, as well as the $O L D, 2115$, s.v. tenebrae.

60 See TLL, s.v. communicatio, coll. 1953, I A.

61 Of course, that the AT used a glossary or a dictionary is, although probable, beyond any proof. However, he might have operated with some kind of a GreekLatin bilingual glossary that merged Greek words and phrases with Latin ones in the form of a vocabulary list, which was not uncommon in late- antique Egypt among Greek speakers at an early stage of learning Latin, see, for example, Adams, Bilingualism, 735. On Greek-Latin glossaries as Latin-learning material in general, see Dickey, Colloquia, 11-12.

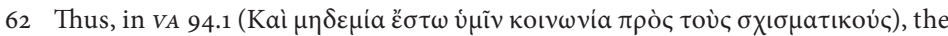
AT has: et non sit uobis communicatio cum schismaticis (vV 94). Compare this to Evagrius' rendering of the same passage: Schismaticorum quoque et haere-

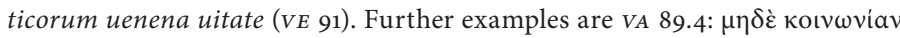

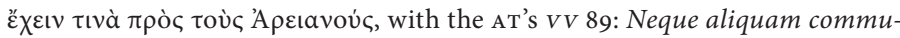
nicationem habueritis cum Arianis, in contrast to VE 89: neque cum Arianis

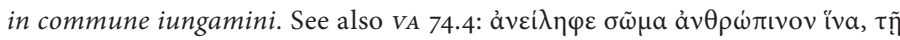

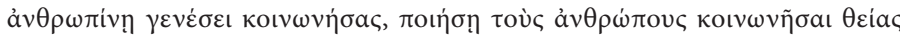

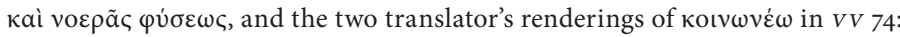
assumpsit corpus humanum ut per communicationem humanae natiuitatis faciat communicare cum diuina illa et intelligibili proprietate, and VE 74: ob salutem nostram humanum corpus assumpserit, ut societate mortalitatis nos ueheret ad caelum participesque naturae caelestis efficeret. 
suggest that Latin was not the native language of the AT; otherwise, the Bible that he would hear in the church would have been in Latin. Not being his native language, Latin would explain the issues the AT faced when translating and the solutions he devised.

\section{EVAGRIUS OF ANTIOCH: LATE-ANTIQUE CHRISTIAN ELITE AND RHETORICAL MASTERY}

Let us now shift our focus to the AT's counterpart, Evagrius, and his handling of biblical material in his Latin translation of the Life. In contrast to the AT, $V E$ is characterized by the translator's familiarity with existing versions of the contemporary Latin Biblical text and his intention to upgrade these existing versions stylistically. Furthermore, the following discussion hopes to demonstrate that Evagrius' decision to adopt such a "free" and "literary" approach to translation was not only of a purely stylistic nature, but that the reasons might be philosophical and ideological as well. ${ }^{63}$

In one of many addresses delivered to his fellow monks on the ascetic and spiritual life, Athanasius' Antony draws on Paul's Epistles to the Romans (Rom. 8:28) and the Corinthians (1 Cor. 15:31), re-

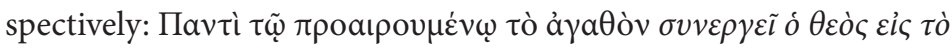

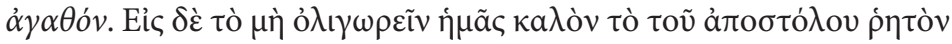

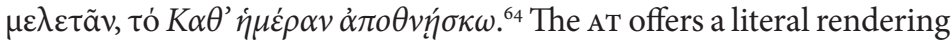
of Athanasius' passage: omni uolenti bonum Deus cooperatur in bono. [...] bonum est meditari Apostoli dictum quod dicit Cotidie morior. ${ }^{65}$ Evagrius, however, provides a somewhat different translation of the same passage: omni proponenti bonum et Deus cooperatur. [...] Apostoli praecepta replicemus quibus se mori quotidie testabatur. ${ }^{66}$

63 A perfect example of a "free," exegetic and stylistically upgraded Evagrius' translation that reflects his rhetorical training and mastery is his per Filium suum propriis Ecclesias ditauerit eloquiis (VE 81, ed. Bertrand, 88): "and that through His Son He enriched the churches with His own words" (trans. White, 60) for

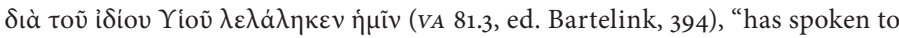
us through his own Son" (trans. Vivian and Athanassakis, 229). See Anđelović, "Between the Literal and the Literary," 66-8.

64 VA 19.1-2 (ed. Bartelink, 214): "God helps everyone to do good who deliberately chooses to do good. Now with regard to losing heart, it is good for us to meditate on the Apostle's statement: 'I die daily.'” (Trans. Vivian and Athanassakis, 103.) VV 19 (ed. Gandt, 123): "To everyone who wants good God assists in good. [...] It is good to meditate on the Apostle's saying which says 'I die daily."

$66 V E 19$ (ed. Bertrand, 25): "To everyone who deliberately chooses [to do] good God helps as well. [...] let us reflect upon the Apostle's words when he claims that he 


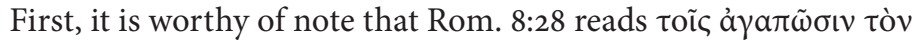

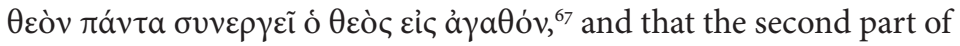

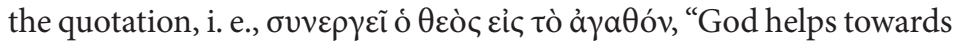
good", is the only part that Athanasius quoted verbatim. This paraphrase of Rom. 8:28 is either a result of Athanasius quoting from memory or his rhetorical strategy in quoting. The first part of Athanasius'

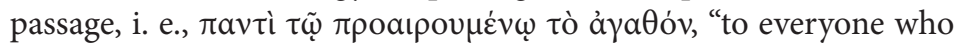
deliberately chooses to do good," is thus added by Athanasius, and it is this wording that is particularly interesting for the analysis of our two translators' renderings of this passage of the Life. The AT's rendering is rather literal, preserving even the word order of the Greek original; the translator kept the two instances of the Greek term tò áya $\theta$ òv and, as a result, has bonum twice in his translation. The second occurrence, i. e., in bono, implies that he was translating verbatim. He probably did so without recourse to any of the circulating Latin versions for Rom. 8:28 because in bono, in the ablative, in this biblical verse, is not attested elsewhere outside the AT's work. ${ }^{68}$ Also, Athanasius' $\pi \rho o a ı \rho \varepsilon \omega$, a critical philosophical term in Antony's discourse meaning "to choose deliberately" was translated in the $v V$ with a simple velle, "to want."

Evagrius, for his part, instead of rendering Athanasius' $\pi \rho \operatorname{la}^{\prime} \rho \dot{\varepsilon} \omega$ with a simple "to want," translated it with propono, which implies primarily moral choice and likewise has a more specific meaning than

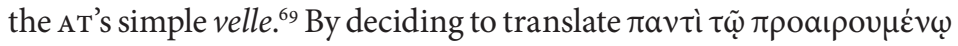
as omni proponenti, Evagrius is in a sense more literal than the AT, however for different reasons than the latter in the examples discussed in the previous section. Evagrius seized the depth and moral

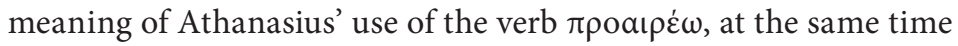
reducing both Athanasius' two occurrences of tò à $\gamma a \theta$ òv and the AT's two bonum into one bonum, probably to avoid repetition and stylistically upgrade this quotation..$^{70}$ Regarding the second biblical quotation from Paul's epistles in this passage of the Life, i. e., 1 Cor.

dies each day." (Trans. White, 21, slightly altered.)

67 "To those who love God, [he] helps in all respects towards [doing] good."

68 The Vulgate version, for instance, has quoniam diligentibus Deum omnia cooperantur in bonum, while Augustine (e. g., Civ. 18.51) writes et diligentibus eum omnia cooperatur in bonum.

69 See the OLD, 1644, s.v. propono, 11A.

70 Another example where Evagrius shortens a biblical quotation is in $V E 55$, where

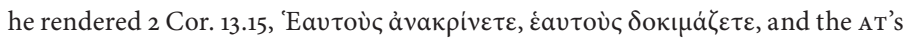
uosmetipsos scrutamini, uosmetipsos probate, as diiudicate uosmetipsos et probate. 


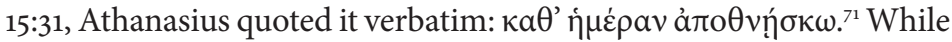
the AT's rendering matches all the other attestations of 1 Cor. 15:31 in Latin from Late Antiquity, ${ }^{72}$ Evagrius, by writing se mori quotidie testabatur, decided to incorporate the biblical quotation into the specific syntactic context of his rendering of Athanasius' passage. However, the two translators' rendering of this biblical quotation is too short to draw general conclusions.

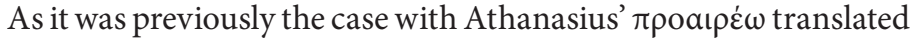
as propono by Evagrius, the latter in a similar way revised Athanasius' $\mu \varepsilon \lambda \varepsilon \tau \tilde{\alpha} v$, "to meditate on [the Apostle's statement]." 73 While the AT simply translated it with meditari, Evagrius' lexical choice was replicare, "to think about and duplicate, to go over and over again [the Apostle's saying]."74 Replicare was not Evagrius' lexical choice made out of purely aesthetic reasons but also a philosophical concept. A ruminative and repetitive nature of replicare enhances

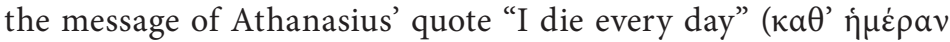
á $\pi 0 \theta v \underline{\sigma} \sigma \kappa \omega),{ }^{75}$ which itself emphasizes the importance of repetitiveness and constancy for ascetic discipline. Emphasizing certain concepts, at times staying close to the Greek original, while sometimes highlighting Athanasius' message by offering a different verb

"I die every day."

The Vulgate has the same wording, as well as Tertullian (Resurr. 48.54), Rufinus (Orig. in Rom. 5.8), Jerome (In Is. 12.41 and Epist. 60.19), and Augustine (Epist. 157.40). This, however, does not mean that the AT shared the same source with the authors as mentioned earlier writing in Latin. The AT could have translated this on his own, as there are not many other ways to translate $\kappa a \theta^{\prime} \dot{\eta} \mu \varepsilon \dot{\varepsilon} \rho v$ ảंo $\theta v \underline{n} \sigma \kappa \omega$ but cotidie morior.

3 On $\mu \varepsilon \lambda \varepsilon \tau \tilde{a} v$ with the meaning "meditatively uttering the words of the Scripture (and especially the Psalms)," see Vivian and Athanassakis, 177, n. 331.

See $O L D, 1785$, s.v. replico, 3.

Discussing the use of replicare by Hugh of St. Victor, Emily Runde has noted that "his use of replicare enforces a sense of cyclical movement, of turning over and unrolling, and of repetition. If they are not to be forgotten or to decay through long disuse (longa intermissione obsolescat), remembered things must be revisited, even literally recollected and put to use." See Runde, "Ways of Reading and Framing Collection," 31. Replicare in general puts a strong emphasis on memory, and as such also means "to recount [events]." Evagrius used replicare four times in his translation of the $V A$, and, apart from the case discussed here, the other three times ( $V E$ 39, 65, and 82) he used it in the meaning "to recount [an event].” It is worth mentioning that in $V E 82$ (ed. Bertrand, 9o), he did not translate anything literally from Greek, but rather quoted Vergil verbatim (Aen. 2.12): horret animus replicare quae gesta sunt, "the mind recoils from repeating what happened." (Trans. White, 61.) 
but also keeping the original meaning, as is the case with replicare, suggests Evagrius' not only different theoretical, but also different philosophical approach to translation than it was the case with the Aт. The following example will further illustrate Evagrius' concern for a crucial philosophical term such as "wisdom" (бopia / sapientia) and how his interventions reshape the meaning of a term and that of Athanasius' message.

In the episode in which Antony debates with philosophers over the true faith, pointing to their "erroneous" beliefs, he attempts to convince them by offering proof for his worship of God. Athanasius' Antony stresses that, if the philosophers are expecting to hear logical proofs made out of wordy fabrications, he will not offer any, and further elaborates on this by quoting 1 Cor. 2:4: i $\mu \varepsilon \tilde{\varsigma} \varsigma$

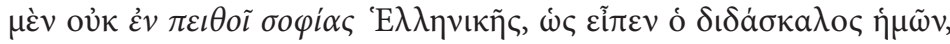

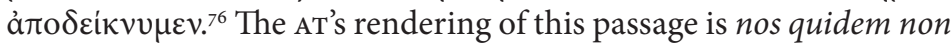
in suadela sapientiae paganorum, ut dixit magister noster, probamus, ${ }^{77}$ while Evagrius translated it as ecce nos, ut dixit Doctor noster, non in gentili persuasione ... suademus. ${ }^{78}$

First, it is noteworthy that the AT translated Athanasius' "our teacher" ( $\delta \mathrm{t} \delta$ á $\sigma \kappa \alpha \lambda \circ \varsigma \dot{\eta} \mu \tilde{\omega} v)$, i. e., the apostle Paul, as magister noster, while for Evagrius he was doctor noster. The AT's magister is a literal translation of $\delta$ เ $\delta \dot{\sigma} \sigma \kappa \alpha \lambda$ oc. Evagrius' lexical choice was, however, by no means literal nor accidental, as he used doctor not only here,

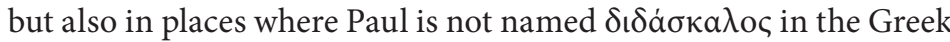
original. ${ }^{79}$ Although doctor is indeed similar to magister in the meaning "teacher," Evagrius' usage of doctor, always coming with noster, sermonum, or eloquium, and referring to Paul, implies that Paul for

76 VA 80.1 (ed. Bartelink, 388): "We will not offer proof by means of 'plausible wisdom' of Greeks, as our teacher said." (Trans. Vivian and Athanassakis, 227, slightly altered: from "plausible Greek wisdom" to "plausible wisdom of Greeks," as 'E $\lambda \lambda \eta \nu เ \kappa \tilde{\eta} \varsigma$, "Greek," is not a part of the biblical quotation 1 Cor. 2:4 and Athanasius added it in the VA.)

$77 V V 80$ (ed. Gandt, 166, slightly altered: suadilla from Gandt's edition and the manuscript to suadela, conjectured by Bartelink, Vita di Antonio, 150): "we will certainly not prove by the persuasion of the wisdom of the pagans, as our teacher said."

$78 V E$ 8o (ed. Bertrand, 86): "look how we convince not by means of the gentiles' attempts at persuasion [...] as our teacher said" (trans. White, 58 , slightly altered, from "pagans" to "gentiles"). Evagrius' rendering of 1 Cor. 2:4 was apparently not recognized as a direct biblical quotation in the latest critical edition by Bertrand.

$79 V E$ 7: doctor sermonum, VE 55: doctor eloquium. 
Evagrius was primarily a teacher in Christian context. ${ }^{80}$ Other prominent Latin patristic authors, with whom, as already shown, Evagrius shared versions of the Bible in Latin, also called Paul doctor gentium, "the teacher of the gentiles."

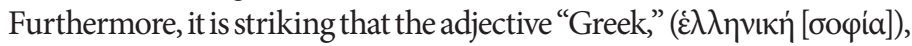
was translated with the term paganus in $v V$, while in $V E$ it was rendered by gentilis. Though the discussion of all the terms for non-Christians in Late Antiquity and an overview of their history and semantic development deserve separate discussion, ${ }^{82}$ in the context of the Life and its translations, Athanasius' "E $\lambda \lambda \eta v$, "Greek," and the translators' paganus and gentilis were all used as negative religious qualifications for non-Christians. The AT resorted to paganus eleven times in his translation, whereas he used

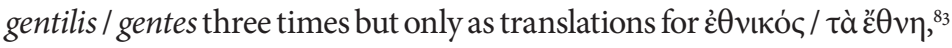
which is certainly not the same as $\dot{\varepsilon} \lambda \lambda \eta v i \kappa o ́ \varsigma^{84}$ The AT thus seems to have

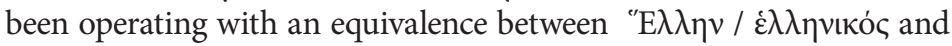
paganus. On the other hand, Evagrius used the adjective gentilis thirteen times in his translation, as opposed to paganus, which is mentioned only three times in the $V E .{ }^{85}$ Thus, in contrast to the AT, Evagrius operated with both options, i. e., paganus and gentilis. The reason why gentilis, and not paganus, was still Evagrius' favorite term for translating "E $\lambda \lambda \eta v / \varepsilon \lambda \lambda$ ๆvikó

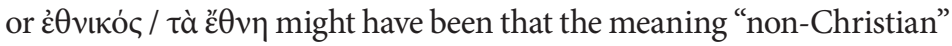
for paganus was a semantic neologism, as reported by Augustine. ${ }^{86}$

As far as their translations of the biblical quotation are concerned, the Aт is the only one to use suadela, "persuasion," to translate $\pi \varepsilon \imath \theta \dot{\omega}$ in this context, which points to a high probability that he

80 "St. Paul speaks of himself as a doctor of the Gentiles in faith and truth (1 Timothy 2:7), and Doctor gentium is one of the titles given to him in the liturgy. In the early Church, teachers in the catechetical schools were known as doctores audientium (Cyprian, Ep. 29); and finally, over time, some of the most illustrious theologians were designated as 'Doctors of the Church." Pace, "Doctor," in The Catholic Encyclopedia, available online.

81 For example, Ambrose (Noe 8.25), Rufinus (Orig. in. gen. 3.4), Augustine (Epist. 157.11), Jerome (In Gal. 1.1).

82 For a detailed overview and discussion on paganus and its relation to gentes, gentiles, or nationes, see Cameron, The Last Pagans, 14-25.

$83 V V 13,45$, and 69 .

84 See Bartelink's commentary ad loc. in Vite dei Santi, 253, n. 70.

85 In $V E 70$ and 72 for "E $\lambda \lambda \eta v$ and in $V E 82$ for $\dot{\varepsilon} \theta v$ เkóc. Similar is the case of Ambrose, for instance, using gentes nineteen times and never pagani, see Cameron, The Last Pagans, 16.

86 Epist. 184A.5: quos uel gentiles uel iam uulgo usitato uocabulo paganos appellare consueuimus. 
was not aware of the existing versions of 1 Cor. 2:4 in Latin. On the other hand, Evagrius' persuasio indicates that he was familiar with an already existing version of 1 Cor. 2:4 in Latin, as witnessed by Ambrose and Jerome. ${ }^{87}$ What is particularly puzzling, however, is not that $V E$, as it usually happens, has parallels in other writers' writing in Latin in Late Antiquity, but that he altogether avoided translating Athanasius' бopia, "wisdom," deeming it sufficient to translate only

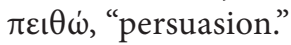

The Greek term бopia, "wisdom," appears four times in the Life. In all four occurrences and contexts, the AT translated it simply as sapientia, without revisions to the Greek text. Such a word-for-word translation is probably due to the translator's adoption of the "one-word-one-concept" strategy, in which бopia always equals sapientia. On the other hand, Evagrius, as mentioned above, did not translate бopia from the Greek original at all. Judging by Evagrius' competence in translating from Greek into Latin, the possibility that he simply overlooked such an important term in Antony's debate over philosophers as бopía should be discarded. Instead, a closer look into his rendering of бopia throughout his translation offers further explanations for Evagrius' particular choice in this case and explains how he employed sapientia.

Out of the four instances where oopia appears in the Greek text, Evagrius translated it as sapientia only once and, even then, he added to it the explanatory term mundi, "of [this] world." ${ }^{\text {88 }}$ Most of the times in the Life, бopia is mentioned with a negative connotation and in a polemic context, in Antony's long speeches against non-Christians who relied on the wisdom of words and this world, as opposed to his "true" faith. Evagrius' reluctance to present "wisdom" as necessarily negative becomes even more apparent when one notices that he attempted to incorporate the noun sapientia in other places in his translation where there was no бopia in corresponding passages of the Greek original. Three times, he employed sapientia with a positive connotation: in a translation of $\varphi \rho$ óv $\eta \sigma \iota \varsigma$ as one of the Christian ideals that lead to heaven, then of voũ $\varsigma$ in Athanasius' words of praise for Antony's intelligence, and in a phrase sapientia bonum est as an addition in the form of an exegetic translation. ${ }^{89}$ On the other hand, in the Evagrian translation, there are precisely three occurrences of

87 Ambrose, In psalm. 47.24.1: non in persuasione sapientiae uerbi; Jerome: Adv. Rufin. 1.17: non in persuasione uerborum.

88 VE 78.

$89 V E 17,85$, and 72 . 
sapientia with a negative connotation: apart from sapientia mundi mentioned above, he used it as uana et confutata sapientia as well as mundana sapientia.9

This is to say, Evagrius was fully aware of what "wisdom" (бopia) meant in Athanasius' discourse and theology and of its connotations. When used alone, sapientia in $V E$ is always presented as a virtue and an advantage; when needed to present it as "empty" wisdom of non-Christians, Evagrius indicated so by adding explanatory terms. It indeed seems as if Evagrius wanted to find a balance between Athanasius' presentation of бopia as a "sin" and what sapientia meant in Evagrius' daily life among literati.

\section{CONCLUSION}

Ever since the discovery of the manuscript with the older anonymous Latin translation, the scholarly stances towards the two Latin translations of the Life of Antony were fixed and viewed them as striking contrasts. It has not been disputable that the $v V$ stands for a literal and an excessively wordy translation, and that, on the other hand, Evagrius' final product is a literary, free, elegant, and stylistically improved translation, composed in high-style Latin by a prominent fourth-century Christian intellectual from Antioch. While all these hold, the two Latin translations of the Life have not been thoroughly mined for all possible information about the two translators.

By discussing the modus operandi of the translators, this research has yielded several discoveries. Firstly, it became apparent that the AT rendered the biblical quotations he found in the Life from Greek into Latin himself without recourse to the available translations. His renderings are unparalleled in other texts that quote the Bible in Latin. In addition, it became apparent that the AT was familiar with the Greek Bible based on the exact verbal correspondences in the word order between several passages in the Greek Bible and the AT's renderings of the biblical quotations, otherwise absent from Athanasius' text. The main conclusion is that his literal and word-for-word approach to translation was not a translation preference but rather a limitation. Namely, the analysis of the AT's mirror and mechanical translations of many terms and several syntactic structures from Greek resulting in non-idiomatic Latin supports the hypothesis that the translator was a bilingual speaker. However, he had insufficient command of the language he was translating into, in this case, Latin. 
On the other hand, this study has shown that Evagrius was using the version of the Bible of which numerous textual parallels are attested in the works of other authors writing in Latin, such as Cyprian, Tertullian, Jerome, Augustine, Rufinus, or Ambrose. While Evagrius' rhetorical education and his translating ad sensum have been noted by various scholars, this study has also shown that Evagrius occasionally stylistically upgraded the language of the existing versions of the Latin Bible, as if he was not content with the material available to him. Evagrius exercised his mastery in rhetoric even on the text that was considered sacred by him and his Christian contemporaries. The investigation of his renderings of biblical quotations from Greek into Latin brought about other important discoveries along the way. For instance, even if Evagrius' close ties with Jerome were acknowledged before, this study has shown that Evagrius and Jerome frequently shared specific wordings of the Bible in Latin that no other Latin author used. This confirms anticipations that Evagrius belonged to the same circle of literati, i. e., the late-antique Christian elite, as Jerome did.

On these grounds, the investigation of how the two translators chose to articulate the text they considered sacred led to discoveries about their linguistic, ideological, and theological backgrounds. Rather than looking for "historical facts" and attempting to "reveal" identities, this article focuses on the very texts, which proved to be fertile research material. After all, this case reminds us of the importance and potential of returning to texts for any philological research. 


\section{BIBLIOGRAPHY}

\section{Primary sources}

Athanasius. "Life of Antony." In Early Christian Lives, edited and translated by Caroline White, 1-71. London: Penguin Books, 1998.

_. Sant'Antonio Abate: La sua vita. Edited by Gerhardus J. M. Bartelink and translated by Luca Bruzzese. Bologna: Edizioni San Clemente and Edizioni Studio Domenicano, 2013.

- The Life of Antony by Athanasius of Alexandria: The Coptic Life and The Greek Life. Translated by Tim Vivian and Apostolos N. Athanassakis. Kalamazoo, Mi: Cistercian Publications, 2003.

—. Vita di Antonio. Edited by Gerhardus J. M. Bartelink. Milano: Fondazione Lorenzo Valla, 1974. Reprint Milano: Fondazione Lorenzo Valla, 2003.

Novum Testamentum Graece: 28th edition. Edited by Christos Karakolis et al. Stuttgart: Deutsche Bibelgesellschaft, 2012.

Septuaginta, id est Vetus Testamentorum graece iuxta LXX interpretes. Edited by Alfred Rahlfs, second revised edition by Robert Hanhart. Stuttgart: Deutsche Bibelgesellschaft, 2006.

Vitae Antonii Versiones latinae: Vita beati Antonii abbatis Evagrio interprete; Versio uetustissima. Edited by Pascal H. E. Bertrand and Lois Gandt. Turnhout: Brepols, 2018.

\section{Secondary sources}

Adams, James N. Bilingualism and the Latin Language. Cambridge: Cambridge University Press, 2004.

Anđelović, Aleksandar. "Between the Literal and the Literary: Social Background, Linguistic Competence, and the Bible in the Late-antique Latin Translations of the Vita Antonii." MA thesis, Central European University, 2021.

Bartelink, Gerhardus J. M. "Die Literarische Gattung der 'Vita Antonii': Struktur und Motive." Vigiliae Christianae 36.1 (1982): 38-62.

Bertrand, Pascal H. E. "Die Evagriusübersetzung der Vita Antonii: Reception - Überliefung - Edition; Unter besonderer Berücksichtigung der Vitas Patrum-Tradition." PhD dissertation, Utrecht University, 2005. 
Brakke, David. "The Greek and Syriac versions of the Life of Antony," Le Muséon 107 (1994): 29-53.

Burton, Philip. The Old Latin Gospels: A Study of their Texts and Language. Oxford: Oxford University Press, 2000.

Cameron, Alan. The Last Pagans of Rome. Oxford: Oxford University Press, 2011.

Denecker, Tim. "Among Latinists: Alfred Ernout and Einar Löfstedt's Responses to the 'Nijmegen School' and its Christian Sondersprache Hypothesis." Historiographia Linguistica 45.3 (2018): 325-62.

_ . "The Nijmegen School and its 'Sociological' Approach to the So-Called 'Sondersprache' of Early Christians: A Preliminary Historiographical Study." Latomus: revue d'études latines 77.2 (2018): 335-57.

Dickey, Eleanor. The Colloquia of the Hermeneumata Pseudodositheana. Cambridge: Cambridge University Press, 2012.

Gandt, Lois. "A Philological and Theological Analysis of the Ancient Latin Translations of the Vita Antonii." PhD dissertation, Fordham University, 2008.

Garitte, Gérard. Un témoin important du texte de La vie de s. Antoine par s. Athanase: La version latine inédite des Archives du Chapitre de S. Pierre à Rome. Bruxelles and Rome: Palais des Académies and Academia Belgica, 1939.

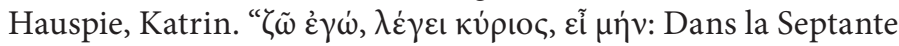
d'Ézéchiel." Bulletin of the International Organization for Septuagint and Cognate Studies 36 (2003): 3-25.

Hoppenbrouwers, Henricus. "La technique de la traduction dans l'Antiquité d'après la première version latine de la Vita Antonii." In Mélanges Christine Mohrmann: Nouveau recueil offert par ses anciens élèves, edited by Christine Mohrmann, 80-95. Utrecht: Spectrum, 1973.

Houghton, Hugh A. G. “'Flattening' in Latin Biblical Citations.” In Papers from the Fifteenth International Patristics Conference, edited by Jane Braun et al., 271-76. Leuven: Peeters Publishers, 2010.

Löfstedt, Einar. Commento Filologico Alla Peregrinatio Aetheriae. Bologna: Pátron Editore, 2007.

Lorié, Ludovicus T. A. Spiritual Terminology in the Latin Translations of the Vita Antonii, with Reference to Fourth and Fifth Century Monastic Literature. Utrecht: Dekker \& van de Vegt, 1955. 
Louth, Andrew. "St. Athanasius and the Greek Life of Antony." Journal of Theological Studies 39 (1988): 504-09.

Rebenich, Stefan. Hieronymus und sein Kreis: Prosopographische und sozialgeschichtliche Untersuchungen. Stuttgart: Franz Steiner Verlag, 1992.

Rousseau, Philip. “Antony as Teacher in the Greek Life.” In Greek Biography and Panegyric in Late Antiquity, edited by Tomas Hägg and Philip Rousseau, 89-109. Berkeley: University of California Press, 2000.

Runde, Emily Christina. "Ways of Reading and Framing Collection in Late Medieval England." PhD dissertation, University of California, 2014.

Wilmart, André. "Une version latine inédite de la vie de saint Antoine." Revue bénédictine 31 (1914): 163-173. 


\section{ABSTRACT}

The paper focuses on the direct Bible quotations that the anonymous translator and Evagrius of Antioch rendered from Greek into Latin as part of their versions of the Life of Antony, each in his own way. Did the anonymous translator use any of the existing fourth-century Latin translations of the Bible to translate the biblical quotations he found in the Greek original, or did he translate them himself, without recourse to translations already available? Which version of the Bible did he use when translating the biblical quotations, in Latin or in Greek? What does the anonymous translator's "literal" and "low-register" style tell us about the translator? Was his non-idiomatic Latin a choice, "Christian" Latin, or rather a limitation in translating into Latin as his target language? On the other hand, what does Evagrius' "high" and stylistically sophisticated and improved Latin tell us about Evagrius? Whom does he write for, and what do his readers expect from him? This paper aims at answering these questions.

KEYWORDS: translation theory, Graeco-Latin bilingualism, hagiography, biblical quotations, late-antique literati, education 
KONTRASTNO JEZIKOVNO IN KULTURNO

OZADJE DVEH LATINSKIH PREVAJALCEV

ANTONOVEGA ŽIVLJENJA

\section{IZVLEČEK}

Pričujoča razprava se osredotoča na neposredne biblijske citate, ki sta jih anonimni prevajalec in Evagrij Antiohijski prestavila iz grščine v latinščino v okviru svojih različic Življenja svetega Antona, vsak na svoj način. Je anonimni prevajalec Življenja uporabil katerega od obstoječih latinskih prevodov Svetega pisma iz četrtega stoletja za prevajanje svetopisemskih citatov, ki jih je našel v grškem izvirniku, ali jih je prevedel sam, ne da bi se zatekel k že dostopnim prevodom? Katero različico Svetega pisma je uporabil pri prevajanju svetopisemskih citatov, latinsko ali grško? Kaj nam o piscu pove »dobesedni« slog anonimnega prevajalca in njegov skromni register? Je bila njegova neidiomatska latinščina izbira, je šlo za »krščansko« latinščino ali za omejenost pri prevajanju v latinščino kot ciljni jezik? Kaj po drugi strani o Evagriju pove njegova "visoka" in slogovno dovršena ter izbrušena latinščina? Za koga piše in kaj od njega pričakujejo bralci? Prispevek skuša odgovoriti na ta vprašanja.

KLJUČNE BESEDE: prevajalska teorija, grško-latinska dvojezičnost, hagiografija, svetopisemski citati, poznoantični literati, izobraževanje 